\title{
Tick-borne bacterial pathogens in southwestern Finland
}

\author{
Jani J. Sormunen ${ }^{1,2}$, Ritva Penttinen³, Tero Klemola', Jari Hänninen², Ilppo Vuorinen², Maija Laaksonen', \\ Ilari E. Sääksjärvi ${ }^{3}$, Kai Ruohomäki ${ }^{1}$ and Eero J. Vesterinen ${ }^{1,4^{*}}$ (D)
}

\begin{abstract}
Background: Ixodes ricinus and Ixodes persulcatus are the main vectors of Lyme borreliosis spirochetes and several other zoonotic bacteria in northern Europe and Russia. However, few studies screening bacterial pathogens in Finnish ticks have been conducted. Therefore, reports on the occurrence and prevalence of several bacterial pathogens detected from ticks elsewhere in Europe and Russia are altogether missing from Finland. The main aim of the current study was to produce novel data on the occurrence and prevalence of several tick-borne bacterial pathogens in ticks collected from southwestern Finland.
\end{abstract}

Methods: Ticks were collected in 2013-2014 by blanket dragging from 25 localities around southwestern Finland, and additionally from a dog in Lempäälä. Collected ticks were molecularly identified and screened for Borrelia burgdorferi s.l, Borrelia miyamotoi, Rickettsia, Bartonella and Candidatus Neoehrlichia mikurensis using quantitative PCR. Furthermore, detected Rickettsia spp. were sequenced using conventional PCR to determine species.

Results: A total of 3169 ticks in 1174 DNA samples were screened for the listed pathogens. The most common bacteria detected was B. burgdorferi (s.l.) (18.5 \% nymphal and $23.5 \%$ adult ticks), followed by Rickettsia spp. (1.1\%; $5.1 \%)$ and B. miyamotoi (0.51 \%; $1.02 \%)$. B. miyamotoi and Rickettsia spp. were also detected in larval samples (minimum infection rates $0.31 \%$ and $0.21 \%$, respectively). Detected Rickettsia spp. were identified by sequencing as $R$. helvetica and R. monacensis. All screened samples were negative for Bartonella spp. and Ca. N. mikurensis.

Conclusions: In the current study we report for the first time the presence of Rickettsia in Finnish ticks. Furthermore, Rickettsia spp. and B. miyamotoi were found from larval tick samples, emphasizing the importance they may have as vectors of these pathogens. Comparisons of tick density estimates and B. burgdorferi (s.l.) prevalence made between the current study and a previous study conducted in 2000 in ten out of the 25 study localities suggest that an increase in tick abundance and B. burgdorferi (s.l.) prevalence has occurred in at least some of the study localities.

Keywords: Ixodes ricinus, Ixodes persulcatus, Tick-borne diseases, Borrelia burgdorferi, Borrelia miyamotoi, Rickettsia, Bartonella, Candidatus Neoehrlichia mikurensis, Finland

\section{Background}

Ticks (Acari: Ixodida) are the primary vectors for several severe zoonotic infections worldwide [1, 2]. A recent survey of 335 emerging infectious disease events indicated that $60.3 \%$ of emerging diseases are zoonoses and that the amount of zoonoses is increasing over time [3]. In Northern Europe and Western Russia, Lyme borreliosis caused by Borrelia burgdorferi (sensu lato) spirochetes is

\footnotetext{
* Correspondence: eero.z.vesterinen@helsinki.fi

${ }^{1}$ Department of Biology, University of Turku, Fl-20014 Turku, Finland

${ }^{4}$ Department of Agricultural Sciences, University of Helsinki, Fl-00014 Helsinki, Finland

Full list of author information is available at the end of the article
}

among the most common and severe zoonotic infections frequently affecting humans [4]. The primary vectors for B. burgdorferi (s.l.) are hard ticks (Ixodidae), in northern Europe and Russia specifically Ixodes ricinus (Linnaeus, 1758) and Ixodes persulcatus (Schulze, 1930). However, in addition to B. burgdorferi (s.l.), humans bitten by ixodids may also be infected with pathogens from several other bacterial genera, which can present themselves through various clinical manifestations.

Bacteria of the genus Borrelia are commonly found in ticks all over the world. These spirochetes are the causative agents for two well-defined human infections: Lyme 
borreliosis and relapsing fever. Lyme borreliosis is caused by Borrelia spp. belonging to the B. burgdorferi (s.l.) species complex. Several B. burgdorferi (s.l.). genospecies have been reported from $I$. persulcatus and $I$. ricinus in Europe, most of which have been shown to cause Lyme borreliosis [5] and have known reservoir hosts [6]. More recently, a species of Borrelia not belonging to the B. burgdorferi (s.l.) species complex has been reported from hard ticks in Europe. This species, Borrelia miyamotoi, belongs to the relapsing fever group of Borrelia, which are usually transmitted by soft ticks (Argasidae). Following the initial detection and description of the pathogen from hard ticks (Ixodes ovatus) in Japan [7], reports of $B$. miyamotoi or B. miyamotoi-like bacteria in Ixodes ticks have been published from over a dozen European countries [8-10]. Whereas Lyme borreliosis cases are relatively common and well documented [4], human patient cases linked with $B$. miyamotoi infection have only been reported recently [11-15].

The bacterial genus Rickettsia is traditionally classified into two groups: the spotted fever group (SFG) and the typhus group [16]. Species from both groups have been found from hard ticks. In Europe, particularly SFG Rickettsia are frequently reported from questing ticks [1721], feeding ticks removed from host animals [22-24], and tissue of host animals [25]. In Northern Europe, Rickettsia helvetica have been reported from Ixodes ticks in Sweden [26-29], Denmark [30, 31], Estonia [32], and Lithuania and Latvia [33]. Furthermore, $R$. monacensis and Candidatus R. tarasevichiae have been reported from Estonian tick populations [32]. Patient cases from Spain and China suggest that the latter two Rickettsia spp. are capable of human infection $[34,35]$.

Bartonella is a genus of gram-negative intracellular bacteria, several species of which are considered to have the potential for human infection [36]. The role of $I$. ricinus as vectors for Bartonella spp. has recently begun to receive increasing scientific attention [36-42]. However, while DNA of various Bartonella spp. has been found from ticks [36], actual vector competence of ticks has only been shown for a few $[39,43]$.

Candidatus Neoehrlichia mikurensis is a candidatestatus species of gram-negative cocci belonging to the family Anaplasmataceae. The first case of human infection in Europe was reported from Sweden, in a patient with recurrent fever episodes [44]. This was soon followed by reports of patient cases in Switzerland and Germany [45, 46]. Candidatus N. mikurensis has been reported from rodents and ticks in Europe, though actual vector competence of ticks has not been shown [47-53]. Nevertheless, due to the high prevalence of the pathogen observed in ticks and rodents in some of the cited studies, it should be considered as a potential tickborne pathogen.
Few studies focusing on tick-borne bacterial pathogens have been conducted in Finland. Consequently, reports regarding the occurrence and prevalence of many tickborne bacterial pathogens found from ticks elsewhere in Europe do not exist for Finland. Concerning Borrelia, Rickettsia, Bartonella and Ca. N. mikurensis, published data of prevalence in Finnish ticks exists only for $B$. burgdorferi (s.l.) and B. miyamotoi [9, 10, 54-57]. The main aim of the current study was to produce novel data of tick-borne bacterial pathogens in Finnish ticks by determining the occurrence and prevalence of Borrelia burgdorferi (s.l.), B. miyamotoi, Rickettsia, Bartonella and Candidatus Neoehrlichia mikurensis in ticks collected from southwestern Finland.

\section{Methods}

Tick collection and sample preparation

Ticks were collected from May (week 20) to September (week 39) in 2013 and 2014 from 25 localities around southwestern Finland (Fig. 1). Ticks were sampled by slowly dragging a $1.0 \mathrm{~m}^{2}$ square cotton cloth along ground floor vegetation in $10 \mathrm{~m}$ sections, for a total of 50-200 m per dragging session in each locality, apart from one of the islands, Seili, where $750 \mathrm{~m}$ were dragged per session. Sampling was done every other or every third week, depending on locality. In Seili, dragging was conducted on study transects as previously described in Sormunen et al. [10]. Elsewhere, dragging was conducted in coniferous and deciduous forests and alder thickets, following classification from a previous study [10]. Furthermore, ticks were collected from a domestic dog in Lempäälä, the only known I. persulcatus focus in southwestern Finland (Fig. 1). Despite recurring tick infestations, to our knowledge, the dog in question has never suffered from any tick-borne diseases.

Ten out of the 25 field survey localities were previously studied by Mäkinen et al. [54]: two city parks in Turku (Samppalinna and Urheilupuisto), two suburban islands (Hirvensalo and Ruissalo) and six rural islands in the Turku archipelago (Seili, Böskar, Berghamn, Pähkinäinen, Maisaari, Vepsä). The remaining 15 study localities had not been investigated before. These novel localities were grouped into three major study lines for logistical reasons: the Coastal line (Askainen, Kustavi, Lokalahti, Pyhämaa, Pyhäranta), the Northern line (Nousiainen, Laitila, Kodisjoki, Eurajoki, Luvia), and the Northwestern line (Alastaro, Matku, Mellillä, Marttila, Paimio) (Fig. 1).

All ticks attached to the cloth were collected using tweezers after each $10 \mathrm{~m}$ drag. Larvae, nymphs, and adults were separated and placed in $1.5 \mathrm{ml}$ Eppendorf tubes. Each adult and nymph was placed in its own tube, with the exception of 153 nymphs, which were placed in 37 randomly sized pools. All larvae collected during a single dragging session (5-20 drags, 50-200 m) in each 


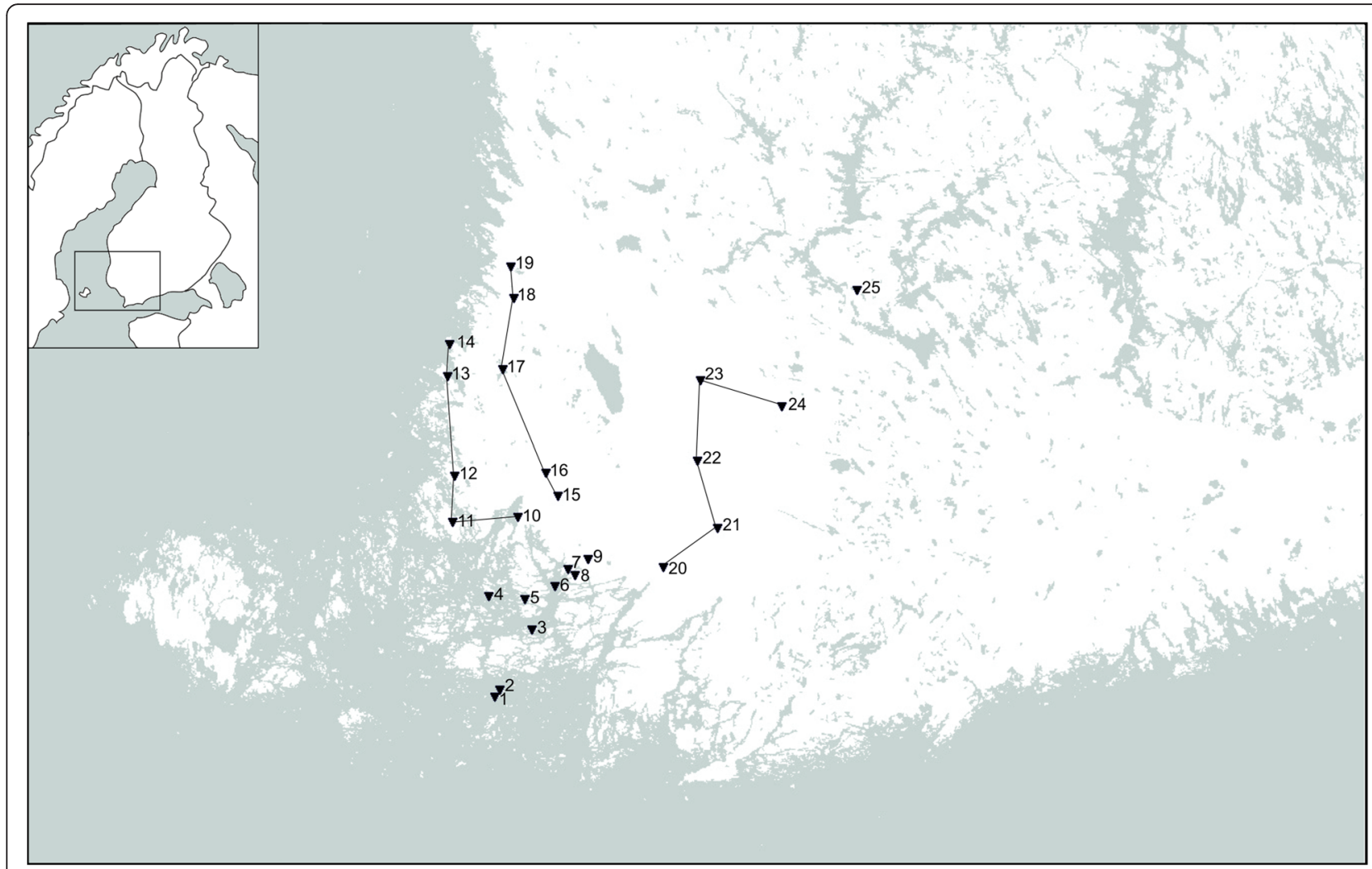

Fig. 1 Field survey and dog tick collection localities in southwestern Finland. 1. Boskär 2. Berghamn 3. Seili 4. Pähkinäinen 5. Maisaari 6. Vepsä 7. Ruissalo 8. Hirvensalo 9. City of Turku; city parks Samppalinna and Urheilupuisto 10. Askainen 11. Kustavi 12. Lokalahti 13. Pyhämaa 14. Pyhäranta 15. Nousiainen 16. Laitila 17. Kodisjoki 18. Eurajoki 19. Luvia 20. Paimio 21. Marttila 22. Mellilä 23. Matku 24. Alastaro 25. Lempäälä

locality were placed in a single tube. The ticks were then transported alive to the Department of Biology in the University of Turku for deep freezing $\left(-80{ }^{\circ} \mathrm{C}\right)$.

Total DNA was extracted from frozen tick samples between June 2014 - March 2015 using NucleoSpin ${ }^{\odot}$ RNA kits and RNA/DNA buffer sets (MachereyNagel, Germany), following the kit protocols (RNA Kit: Rev. 16/May 2014 and RNA/DNA buffer set: Rev. 08/May 2014). RNA extracts were stored at $-80{ }^{\circ} \mathrm{C}$ for later use. DNA extracts were stored at $-20{ }^{\circ} \mathrm{C}$.

Analyses regarding tick species and Borrelia spp. prevalence were carried out on individual DNA samples. For screening of Rickettsia, Bartonella, and Candidatus Neoehrlichia mikurensis, aliquots of original DNA samples were pooled (ten samples per pool, $5 \mu \mathrm{l}$ of each sample) to make the procedure faster and more costefficient due to low expected prevalence. Original, separate DNA samples were re-analyzed as needed when a pooled sample was found positive.

\section{Real-time qPCR}

Real-time quantitative PCR (henceforth abbreviated qPCR) assays were carried out using KAPAProbe FAST PCR Kit (product number KK4706; KAPA Biosystems,
Wilmington, Massachusetts, USA). All samples were analyzed in three replicate reactions carried out on 384well plates. At least three blank water samples were used as negative controls in each assay. The thermal cycling profile used was $95{ }^{\circ} \mathrm{C}$ for $3 \mathrm{~min}$, then 50 cycles of $95{ }^{\circ} \mathrm{C}$ for $3 \mathrm{~s}$ and $60{ }^{\circ} \mathrm{C}$ for $30 \mathrm{~s}$. Thermal cycling was carried out at Finnish Microarray and Sequencing Centre (FMSC, Turku, Finland) using QuantStudio $12 \mathrm{~K}$ Flex Real-Time PCR System (Life Technologies Inc. [LTI], Carlsbad, CA). All qPCR results were analyzed using QuantStudio $^{\text {тм }} 12$ K Flex Software v.1.2.2 (LT1). Samples were considered positive only when successful amplification was detected in all three replicate reactions.

\section{Tick species determination}

Tick species was determined in a species-specific duplex qPCR assay. We designed primers IXO-I2-F4 and IXO-I2R4 targeting the Ixodes spp. ITS2 gene to amplify genus specific segments (Table 1). Species-specific probes IpeI2-P4 and Iri-I2-P4 were designed to match either of the tick species (I. persulcatus and I. ricinus, respectively) (Table 1). This approach is very cost-efficient and gives the advantage to simultaneously detect both species present in large pools. Assays were carried out in $5 \mu \mathrm{l}$ 
Table 1 Primers and probes used in tick species determination and pathogen screening

\begin{tabular}{|c|c|c|c|}
\hline Primer/probe name & Primer/probe target & $5^{\prime} \rightarrow 3^{\prime}$ & Reference \\
\hline \multicolumn{4}{|l|}{ qPCR: } \\
\hline IXO-I2-F4 & Ixodes spp. ITS2 & TCTCGTGGCGTTGATTTGC & This paper \\
\hline IXO-I2-R4 & Ixodes spp. ITS2 & CTGACGGAAGGCTACGACG & \\
\hline Ipe-12-P4 & 1. persulcatus ITS2 & [FAM]-TGCGTGGAAAGAAAACGAG-[BHQ1] & \\
\hline |ri-12-P4 & 1. ricinus ITS2 & [VIC]-TGCTCGAAGGAGAGAACGA-[BHQ1] & \\
\hline $\mathrm{Bb} 23 \mathrm{Sf}$ & B. burgdorferi 23S RNA & CGAGTCTTAAAAGGGCGATTTAGT & Courtney et al. [83] \\
\hline $\mathrm{Bb} 23 \mathrm{Sr}$ & B. burgdorferi 23S RNA & GCTTCAGCCTGGCCATAAATAG & \\
\hline Bb23Sp & B. burgdorferi $235 \mathrm{RNA}$ & [FAM]-AGATGTGGTAGACCCGAAGCCGAGTG-[BHQ1] & \\
\hline Bmi-F & B. miyamotoi glpQ & CACGACCCAGAAATTGACACA & Vayssier-Taussat et al. [84] \\
\hline Bmi-R & B. miyamotoi glpQ & GTGTGAAGTCAGTGGCGTAAT & \\
\hline Bmi-P & B. miyamotoi glpQ & [FAM]-TCGTCCGTITTCTCTAGCTCGATTGGG-[BHQ1] & \\
\hline Bart-ssRA-F & Bartonella ssRa & GCTATGGTAATAAATGGACAATGAAATAA & Diaz et al. [85] \\
\hline Bart-ssRA-R & Bartonella ssRa & GCTTCTGTTGCCAGGTG & \\
\hline Bart-ssRA-P & Bartonella ssRa & [FAM]-ACCCCGCTTAAACCTGCGACG-[BHQ1] & \\
\hline Rspp-F & Rickettsia gltA & GAGAGAAAATTATATCCAAATGTTGAT & Labruna et al. [86] \\
\hline Rspp-R & Rickettsia gltA & AGGGTCTTCGTGCATTTCTT & \\
\hline Rspp-P & Rickettsia gltA & [CY5]-CATTGTGCCATCCAGCCTACGGT-[BHQ3] & \\
\hline CNe-F & Ca. N. mikurensis groEL & AGAGACATCATTCGCATTTTGGA & Vayssier-Taussat et al. [84] \\
\hline CNe-R & Ca. N. mikurensis groEL & TTCCGGTGTACCATAAGGCTT & \\
\hline CNe-P & Ca. N. mikurensis groEL & [TAMRA]-AGATGCTGTTGGATGTACTGCTGGACC-[BHQ2] & \\
\hline \multicolumn{4}{|l|}{ PCR: } \\
\hline CS877f & Rickettsia gltA & TAATACGACTCACTATAGGGGGGGACCTGCTCACGGCGG & Mediannikov et al. [87] \\
\hline CS1258r & Rickettsia gltA & ATTAACCCTCACTAAAGATTGCAAAAAGTACAGTGAACA & \\
\hline
\end{tabular}

reaction volume, including $2.5 \mu \mathrm{l}$ KAPAProbe FAST PCR Kit, $200 \mathrm{nM}$ forward primer, $200 \mathrm{nM}$ reverse primer, 150 nM Iri-I2-P4 probe, $100 \mathrm{nM}$ Ipe-I2-P4 probe, $1.175 \mu \mathrm{l}$ $\mathrm{ddH} 2 \mathrm{O}$, and $1 \mu \mathrm{l}$ DNA. The newly designed primers and probes were tested by amplifying hundreds of sequenced I. ricinus and I. persulcatus DNA samples from an earlier study [10]. DNA samples of I. ricinus and I. persulcatus confirmed by sequencing were used as positive controls in each assay.

\section{Pathogen screening}

DNA samples were screened for Borrelia burgdorferi (s.l.) and B. miyamotoi using qPCR. For Borrelia burgdorferi (s.l.) we used primers targeting 23S rRNA of $B$. burgdorferi (s.l.) (Bb23Sf and Bb23Sr) and a dual-labeled probe, Bb23Sp (Table 1). For B. miyamotoi we used primers targeting the $g l p Q$ gene (Bmi-F and Bmi-R) and a dual-labeled probe, Bmi-P (Table 1). Both assays were carried out in $5 \mu \mathrm{l}$ reaction volume, including $2.5 \mu \mathrm{l}$ KAPAProbe FAST PCR Kit, $200 \mathrm{nM}$ forward primer, $200 \mathrm{nM}$ reverse primer, $100 \mathrm{nM}$ probe, $1.25 \mu \mathrm{lddH} 2 \mathrm{O}$, and $1 \mu \mathrm{l}$ DNA. DNA samples of B. burgdorferi (s.l.) and $B$. miyamotoi confirmed by sequencing in an earlier study [10] were used as positive controls.
Furthermore, aliquots of original DNA samples were pooled for screening of Bartonella, Rickettsia, and Candidatus Neoehrlichia mikurensis (see Tick collection and sample preparation). For Bartonella and Rickettsia we used a duplex qPCR assay with primers targeting Bartonella ssrA (Bart-ssRA-F and Bart-ssRA-R) and Rickettsia gltA (Rspp-F and Rspp-R), and dual-labeled probes BartssRA-P and Rspp-P (Table 1). Assays were carried out in $8 \mu \mathrm{l}$ reaction volume, including $4 \mu \mathrm{l}$ KAPAProbe FAST PCR Kit, 200 nM Bartonella forward and reverse primers, $300 \mathrm{nM}$ Rickettsia forward and reverse primers, $100 \mathrm{nM}$ Bartonella probe, $150 \mathrm{nM}$ Rickettsia probe, and $3 \mu \mathrm{l}$ of pooled DNA sample. Patient strains of Bartonella grahamii and B. quintana were used as positive controls for Bartonella assays. Both strains showed successful amplification in every assay. For Rickettsia we used a commercially available control sample (ref. MBC042; Vircell, Granada, Spain).

For Candidatus Neoehrlichia mikurensis, we used primers targeting the groEL gene ( $\mathrm{CNe}-\mathrm{F}$ and $\mathrm{CNe}-\mathrm{R})$ and a dual-labeled probe, $\mathrm{CNe}-\mathrm{P}$ (Table 1). Assays were carried out in $7 \mu \mathrm{l}$ reaction volume, including $3.5 \mu \mathrm{l}$ KAPAProbe FAST PCR Kit, $300 \mathrm{nM}$ forward primer, $300 \mathrm{nM}$ reverse primer, $300 \mathrm{nM}$ probe, $0.87 \mu \mathrm{lddH} 2 \mathrm{O}$ 
and $2 \mu \mathrm{l}$ pooled DNA. No positive controls were available to us for $\mathrm{Ca}$. N. mikurensis.

Original, separate DNA samples in pools positive for Bartonella, Rickettsia or Candidatus Neoehrlichia mikurensis were subsequently individually re-analyzed using the qPCR (Table 1). Samples were analysed in $5 \mu \mathrm{l}$ reaction volume, including $2.5 \mu \mathrm{l}$ KAPAProbe FAST PCR Kit, 200 $\mathrm{nM}$ forward primer, $200 \mathrm{nM}$ reverse primer, $100 \mathrm{nM}$ probe, $1.25 \mu \mathrm{lddH} 2 \mathrm{O}$ and $1 \mu \mathrm{l}$ DNA.

\section{Sequencing}

Samples found positive for Rickettsia by qPCR were sequenced using conventional PCR primers (CS877f and CS1258r) targeting Rickettsia gltA gene (Table 1). PCR was carried out in $12.5 \mu \mathrm{l}$ reaction volume containing $3 \mu \mathrm{l}$ of DNA extract, $2.75 \mu \mathrm{lddH} 2 \mathrm{O}, 6.25 \mu \mathrm{l}$ MyTaq Red Mix polymerase mix (product number BIO-25048, Bioline, England), $500 \mathrm{nM}$ forward primer, and $500 \mathrm{nM}$ reverse primer. Water samples were used as blank controls in each PCR batch. Thermal cycling was performed with the following program: $95{ }^{\circ} \mathrm{C}$ for $3 \mathrm{~min}$, then 35 cycles of $95^{\circ} \mathrm{C}$ for $20 \mathrm{~s}, 60^{\circ} \mathrm{C}$ for $30 \mathrm{~s}$, and $72^{\circ}$ $\mathrm{C}$ for $1 \mathrm{~min}$. The PCR products were purified by mixing $1 \mu \mathrm{l}$ EXO I enzyme, $1 \mu \mathrm{l}$ rSAP enzyme, $3 \mu \mathrm{l}$ of ddH2O, and $5 \mu \mathrm{l}$ of PCR product, after which the samples were first incubated $5 \mathrm{~min}$ at $37{ }^{\circ} \mathrm{C}$ and then heated $10 \mathrm{~min}$ at $80{ }^{\circ} \mathrm{C}$. Purified samples were sent to Macrogen Inc. Europe (The Netherlands) for sequencing. The sequences were trimmed using Geneious version 6 [58] and run through BLAST (www.ncbi.nlm.nih.gov/BLAST/). The trimmed sequences were then further compared to reference sequences of the Rickettsia species detected in BLAST, downloaded from GenBank (www.ncbi.nlm.nih.gov/genbank/), to ascertain species using the software Geneious Pro R6 [59]. The reference sequences used in this study were Rickettsia helvetica [GenBank: KF447530] and R. monacensis [GenBank: KM198341].

\section{Results}

A total of 3169 ticks were collected during the study. All ticks collected by dragging from southwestern Finland (3158 ticks) were identified as Ixodes ricinus by qPCR. In addition, eleven samples were collected from a dog in Lempäälä and first identified morphologically [60], and subsequently by means of qPCR, as I. persulcatus. Larvae were the most numerous life stage with 1939 individuals collected $(61.20 \%$ of all ticks collected), followed by nymphs at 1132 individuals (35.70 \%) and adults at 98 individuals $(3.10 \%)$. Tick density estimates in each of the study localities are reported in Table 2 .

A total of 3169 ticks in 1174 DNA samples were screened for Borrelia burgdorferi (s.l.), B. miyamotoi, Bartonella, Rickettsia, and Candidatus Neoehrlichia mikurensis. DNA samples consisted of 98 adults, 979 nymphs, 60 larval pools (1-111 individuals per sample; 1939 larvae in total), and 37 nymph pools (2-16 individuals per sample; 153 nymphs in total). Individuals from nymph and larval pools were not used in prevalence calculations.

Table 2 Tick density estimates and the number of positive samples in each locality in this study

\begin{tabular}{|c|c|c|c|c|c|c|c|}
\hline \multirow[t]{2}{*}{ Study locality } & \multirow[t]{2}{*}{$\begin{array}{l}\text { Tick density } \\
\left(\text { ticks } / 100 \mathrm{~m}^{2}\right)\end{array}$} & \multirow[t]{2}{*}{$\begin{array}{l}\text { Tick density (ticks/100 } \mathrm{m}^{2} \text { ) } \\
\text { without larvae }\end{array}$} & \multirow[t]{2}{*}{$\begin{array}{l}\text { Tick density in } 2000 \\
\left(\text { ticks } / 100 \mathrm{~m}^{2}\right)^{\mathrm{d}, \mathrm{e}}\end{array}$} & \multicolumn{2}{|c|}{ B. burgdorferi (s.l.) prevalence ${ }^{f}$} & \multicolumn{2}{|c|}{$\begin{array}{l}\text { B. burdorferi (s.l.) prevalence } \\
\text { in } 2000^{\mathrm{d}}\end{array}$} \\
\hline & & & & Samples & Positive (\%) & Samples & Positive (\%) \\
\hline Boskär & $406.0^{9}$ & 36.0 & 7.3 & 160 & $47(29.4)$ & 272 & $13(4.8)$ \\
\hline Berghamn & 22.0 & 8.3 & 0.93 & 20 & $1(5.0)$ & 66 & $0(0)$ \\
\hline Seili & 27.4 & 5.6 & 0.28 & 722 & $126(17.5)$ & 69 & $8(11.6)$ \\
\hline Pähkinäinen & 28.3 & 9.6 & 0.82 & 88 & $18(20.5)$ & 22 & $2(9.1)$ \\
\hline Maisaari & 2.0 & 1.6 & 0.06 & 18 & $4(22.2)$ & 2 & 0 \\
\hline Vepsä & 1.81 & 1.4 & 0.2 & 9 & $2(22.2)$ & 8 & 0 \\
\hline Hirvensalo & 2.22 & 2.0 & 0.01 & 9 & $1(11.1)$ & 1 & 0 \\
\hline Ruissalo & 0.6 & 0.6 & 0.23 & 10 & 0 & 14 & 0 \\
\hline Samppalinna & 0 & 0 & 0 & 0 & - & 0 & - \\
\hline Urheilupuisto & 0 & 0 & 0 & 0 & - & 0 & - \\
\hline Coastal line ${ }^{a}$ & 2.0 & 1.9 & $\mathrm{n} / \mathrm{a}$ & 27 & $4(14.8)$ & $\mathrm{n} / \mathrm{a}$ & \\
\hline Northern line ${ }^{b}$ & 0.13 & 0.13 & $\mathrm{n} / \mathrm{a}$ & 3 & 0 & $\mathrm{n} / \mathrm{a}$ & \\
\hline Northwestern line ${ }^{c}$ & 0 & 0 & $\mathrm{n} / \mathrm{a}$ & 0 & - & $\mathrm{n} / \mathrm{a}$ & \\
\hline
\end{tabular}

${ }^{\mathrm{a}}$ Coastal line: Askainen, Kustavi, Lokalahti, Pyhämaa, Pyhäranta

${ }^{\mathrm{b}}$ Northern line: Nousiainen, Mynämäki, Laitila, Eurajoki, Luvia

${ }^{c}$ Northwestern line: Alastaro, Matku, Mellilä, Marttila, Paimio

${ }^{\mathrm{d}}$ Data from Mäkinen et al. [54]

'Tick densities measured for nymphs and adults in 2000

fPrevalence measured for nymphs and adults together, as in Mäkinen et al. [54]

${ }^{9}$ In Boskär, larval densities were approximated due to extremely high numbers of larvae (occasionally $500-600$ larvae per $50 \mathrm{~m}$ drag) 
Borrelia burgdorferi (s.l.) were detected in 217 DNA samples (Table 3). Positive samples consisted of 23 adult ticks, 181 nymphs, and 13 nymph pools (87 individuals). Prevalence of B. burgdorferi (s.l.) was $23.5 \%$ for adults and $18.5 \%$ for nymphs. The minimum infection rate (MIR) calculated for pooled nymphs was $8.5 \%$.

Borrelia miyamotoi were detected in 16 DNA samples (Table 3). These consisted of one adult male, five individual nymphs, four nymph pools (21 individuals) and six larval pools (282 individuals). B. miyamotoi prevalence was $1.02 \%$ for adults and $0.51 \%$ for individual nymphs. Minimum infection rates (MIR) were $2.61 \%$ for pooled nymphs and $0.31 \%$ for pooled larvae.

Rickettsia spp. were detected in 21 DNA samples (Table 2). Positive samples consisted of five adults, 11 nymphs, one nymph pool (two individuals), and four larval pools (216 individuals). These accounted for a prevalence of $5.10 \%$ for adults and $1.10 \%$ for nymphs. Minimum infection rates were $0.65 \%$ for pooled nymphs and $0.21 \%$ for pooled larvae. Furthermore, 20 out of the 21 positive samples were sequenced to determine Rickettsia spp. One sample had ran out prior to this and could therefore not be sequenced. Sixteen sequenced samples were identified as $R$. helvetica and three as $R$. monacensis (sequence identity $99-100 \%$ with corresponding reference sequences). One sample could not be identified due to poor quality of sequencing data.

Site-specific prevalence of the detected pathogens is reported in Table 3. Regarding pooled samples, which are not reported in Table 3, B. miyamotoi were found from two nymph pools from Seili and six larval pools from Boskär. Rickettsia spp. were found from a single nymph pool and three larval pools from Seili and one larval pool from Boskär.
Co-infection by B. burgdorferi (s.l.) and Rickettsia was detected in three samples. These samples were an adult male and two nymphs from Seili. All co-infecting Rickettsia spp. were identified as $R$. helvetica. The rate of double infections was $1.02 \%$ for adults and $0.20 \%$ for nymphs. Both $B$. miyamotoi and $R$. monacensis were detected in a larval pool from Boskär, but whether they were carried by the same individual could not be determined.

All samples were negative for Bartonella spp. and Candidatus Neoehrlichia mikurensis.

\section{Discussion}

In the present study, ticks were collected by cloth dragging from 25 localities around southwestern Finland. The highest densities of $I$. ricinus were measured from rural islands in the Turku Archipelago, which were also previously studied in 2000 [54] (Fig. 1, Table 2). Compared to previous results, higher tick densities were observed in all study localities that yielded ticks. However, these temporal comparisons were made between two years only, except in Seili, where high tick densities were measured also in 2012 and 2015 (Sormunen et al. [10] and unpublished). Further surveys of tick abundance in the study localities are required to more conclusively determine if an increase in tick abundance has occurred and whether similar tick densities can be observed persistently.

A decrease in tick densities was observed when moving to the mainland from the archipelago and/or inland from the coastline (Table 2, Fig. 1). No ticks were found from the two city parks in Turku (Samppalinna and Urheilupuisto) in either 2000 or 2013 [54], despite similar localities in the capital city Helsinki having high tick

Table 3 Prevalence of B. burgdorferi (s.I.), B. miyamotoi and Rickettsia spp. in single-stored adult and nymphal ticks

\begin{tabular}{|c|c|c|c|c|c|c|c|c|c|c|c|c|}
\hline \multirow[t]{2}{*}{ Study area } & \multicolumn{3}{|c|}{ No. of DNA samples } & \multicolumn{3}{|c|}{$\begin{array}{l}\text { No. (\%) of samples positive for } \\
\text { B. burgdorferi (s.l.) }\end{array}$} & \multicolumn{3}{|c|}{$\begin{array}{l}\text { No. (\%) of samples positive for } \\
\text { B. miyamotoi }\end{array}$} & \multicolumn{3}{|c|}{$\begin{array}{l}\text { No. (\%) of samples positive for } \\
\text { Rickettsia spp. }\end{array}$} \\
\hline & $\overline{\mathrm{Ad}^{\mathrm{a}}}$ & $N^{a}$ & $\overline{\text { Overall }}$ & $\mathrm{Ad}$ & $\mathrm{N}$ & Overall & $\mathrm{Ad}$ & $\mathrm{N}$ & Overall & $\mathrm{Ad}$ & $\mathrm{N}$ & Overall \\
\hline Boskär & 11 & 149 & 160 & $1(9.1)$ & $46(30.9)$ & $47(29.4)$ & 0 & $1(0.67)$ & $1(0.63)$ & 0 & $1(0.67)$ & $1(0.63)$ \\
\hline Berghamn & 1 & 19 & 20 & 0 & $1(5.3)$ & $1(5.0)$ & 0 & 0 & 0 & 0 & 0 & 0 \\
\hline Seili & 57 & 665 & 722 & $14(24.6)$ & $112(16.8)$ & $126(17.5)$ & $1(1.8)$ & $3(0.45)$ & $4(0.56)$ & $3(5.3)$ & $10(1.5)$ & $13(1.8)$ \\
\hline Pähkinäinen & 5 & 83 & 88 & $2(40.0)$ & $16(19.3)$ & $18(20.5)$ & 0 & $1(1.2)$ & $1(1.1)$ & $1(20.0)$ & 0 & $1(1.1)$ \\
\hline Maisaari & 2 & 16 & 18 & $1(50.0)$ & $3(18.8)$ & $4(22.2)$ & 0 & 0 & 0 & 0 & 0 & 0 \\
\hline Vepsä & 4 & 5 & 9 & $2(50.0)$ & 0 & $2(22.2)$ & 0 & 0 & 0 & 0 & 0 & 0 \\
\hline Ruissalo & 3 & 7 & 10 & 0 & 0 & 0 & 0 & 0 & 0 & 1 (33.3) & 0 & $1(10.0)$ \\
\hline Hirvensalo & 0 & 9 & 9 & - & $1(11.1)$ & $1(11.1)$ & - & 0 & 0 & - & 0 & 0 \\
\hline Coastal line & 4 & 23 & 27 & $2(50.0)$ & $2(8.7)$ & $4(14.8)$ & 0 & 0 & 0 & 0 & 0 & 0 \\
\hline Northern line & 0 & 3 & 3 & - & 0 & 0 & - & 0 & 0 & - & 0 & 0 \\
\hline Lempäälä & 11 & 0 & 11 & $1(9.1)$ & - & $1(9.1)$ & 0 & - & 0 & 0 & - & 0 \\
\hline Total & 98 & 979 & 1077 & $23(23.5)$ & 181 (18.5) & 204 (18.9) & $1(1.02)$ & $5(0.51)$ & $6(0.56)$ & $5(5.1)$ & $11(1.1)$ & $16(1.5)$ \\
\hline
\end{tabular}

${ }^{\text {a }}$ Abbreviations: Ad adults; $\mathrm{N}$ nymphs 
densities (mean 16.3/100 $\mathrm{m}^{2}$ ) [56]. It should be noted, however, that our studies in the city parks were focused mainly on assessing the threat that ticks pose to humans. Therefore, dragging was conducted mostly in locations utilized by citizens for recreational purposes, which were not necessarily optimal for ticks. Nevertheless, some ticks would be expected to have been caught if densities were similar to those observed in Helsinki. Thus, it seems that some unidentified ecological factors (such as certain important host animals) affecting Ixodes spp. occurrence are still lacking in the city parks of Turku, as suggested previously by Mäkinen and colleagues [54].

Borrelia burgdorferi (s.l.) was the most prevalent of the screened pathogens. Similar results have been reported in other studies concerning the prevalence of various pathogens found from I. ricinus in Europe [30, 47, 6163]. Furthermore, the life stage distribution of infected ticks conforms to results reported from all over Europe $[64,65]$, with adults having noticeably higher B. burgdorferi (s.l.) prevalence than nymphs. The adult and nymphal prevalence observed in the current study ( 23.5 and $18.5 \%$ ) were somewhat higher than the averages reported from Europe (18.6 and $10.1 \%$, respectively) [64], though much geographical variation in prevalence is known to exist. All larval samples analyzed were negative for B. burgdorferi (s.l.) infection. Since prevalence was high in adults and nymphs collected from the same study localities, this finding supports the notion that transovarial transmission of $B$. burgdorferi (s.l.) from adult females to larvae is at most an exceedingly rare occurrence [66].

Mäkinen and colleagues previously investigated $B$. burgdorferi (s.l.) prevalence of $I$. ricinus in ten of the study localities investigated in the present study [54]. Compared to these results from the year 2000, an apparent increase in prevalence can be observed across all study localities that yielded ticks, apart from Ruissalo (Table 2). While the results of the comparison presented here should be interpreted with caution due to relatively low sample sizes, the uniformity of observed changes suggests that an actual increase in prevalence has occurred in at least some of the study localities (e.g. Boskär, Seili, and Pähkinäinen).

Borrelia miyamotoi was found from all tick life stages (infection rates for adults: $1.02 \%$; individual nymphs $0.51 \%$; pooled nymphs (MIR) $2.61 \%$; and pooled larvae (MIR) $0.31 \%$ ). The prevalence observed for adults and nymphs in the current study conforms to surveys conducted elsewhere in Europe, which have reported modest prevalence rates $(0.17-3.8 \%)[8,67,68]$. In Finland, screening of individual ticks for $B$. miyamotoi has previously been conducted only on the Åland Islands [9]. As a results, only this single reference for typical B. miyamotoi prevalence exists $(0.51 \%$ overall; $0.81 \%$ for adults;
$0.20 \%$ for nymphs) [9]. Because higher prevalences have been observed elsewhere [69-71], it is evident that $B$. miyamotoi spirochetes can achieve higher prevalence given suitable conditions and time. Therefore, foci with low prevalence could be either recently infested or in ecologically suboptimal areas. In samples from Seili island, B. miyamotoi has been identified for three consecutive years (2012-2014; Table 3; see Sormunen et al. [10] for 2012 data), though prevalence has remained low (0.47-0.68\%). These consecutive findings suggest that Seili is a locality endemic for the spirochete. Borrelia miyamotoi has now been reported from four localities in Finland: the Åland Islands and Seili Island previously [9, 10], and Pähkinäinen and Boskär in the current study (Table 3).

Rickettsia spp. were found from $5.10 \%$ of adult and $1.10 \%$ of nymphal ticks (overall prevalence $1.50 \%$ ). There seems to be great variation in Rickettsia spp. prevalence in European tick populations, ranging from values similar to those reported here to considerably higher (1.9-58 \% for adults; $1.12-18 \%$ for nymphs; $1.7-$ $16 \%$ in studies where adults and nymphs were combined) [26, 28, 62, 63, 72-74]. While Rickettsia spp. have been reported from ticks in many European countries, they have not been screened from Finnish ticks before. In neighboring Sweden, with similar climatic conditions, high variation in Rickettsia spp. prevalence has been observed [26-29]. Most Rickettsia spp. reported from Swedish ticks have been identified as $R$. helvetica. In the current study, $R$. helvetica and $R$. monacensis were detected in ticks collected from southwestern Finland (Table 3). While the presence of $R$. helvetica was expected based on the studies conducted in Sweden, the detection of $R$. monacensis was somewhat unexpected. This species has been reported from ticks in nearby Poland and Estonia [32, 75], but no findings have been reported from questing ticks in the northern countries of the Baltic region. The ecology and epidemiology of $R$. monacensis are still relatively unknown, but patient cases from Spain and Italy suggests that it is capable of human infection $[35,76]$. With the presence of at least two potentially pathogenic species confirmed in ticks in southwestern Finland, further efforts should be made to more broadly study the occurrence and prevalence of Rickettsia in Finnish ticks.

As initial pathogen uptake and infection of ticks usually takes place during feeding, the role of I. ricinus and I. persulcatus larvae as vectors for human infections is mostly limited to pathogens capable of transovarial transmission. Consequently, larvae seem to have received less attention than adult and nymphal ticks in studies of tick-borne diseases [64]. However, recent studies have revealed that B. miyamotoi, Ca. N. mikurensis, and certain species of Rickettsia are likely capable of 
both transovarial transmission and human infection $[11-15,19,66,67,77-79]$. In the present study, $R$. helvetica, $R$. monacensis, and B. miyamotoi were detected in larval samples. Minimum infection rates for pooled larvae were $0.21 \%$ for Rickettsia spp. and $0.31 \%$ for $B$. miyamotoi. These findings suggest that these bacteria can indeed be found from wild questing I. ricinus larvae, thus supporting the notion that transovarial transmission occurs naturally in tick populations. Consequently, tick larvae should also be considered as potential health risks in areas endemic for $B$. miyamotoi and Rickettsia spp.

All screened samples of this study were negative for Bartonella and $\mathrm{Ca}$. N. mikurensis infection. However, no positive controls for $\mathrm{Ca}$. N. mikurensis were available to us at the time of the analysis. Therefore, the negative results regarding $\mathrm{Ca}$. N. mikurensis should be interpreted with care. These pathogens have not been screened from Finnish ticks before. Candidatus N. mikurensis has been reported from ticks and/or host animals in nearby Germany, Russia, Sweden, and Denmark [47-52]. Bartonella have been reported from ticks in Germany and Russia, but surveys in Sweden have been negative [37, $38,80]$. While the relevance of ticks as vectors for human bartonellosis is still debated [36, 81, 82], I. ricinus has been shown to be a competent vector for some Bartonella spp. $[39,43]$. Still, as far as we are aware, no patient cases of human bartonellosis have been incontrovertibly linked to tick bites. The same is true for $\mathrm{Ca}$. N. mikurensis patient cases reported from Sweden, Switzerland, Germany and the Czech Republic in Europe [44-46]. However, for Ca. N. mikurensis, knowledge regarding other possible vectors for human infection is missing. As the prevalence and ability of these pathogens to be transmitted to humans via a tick bite are still under survey, it is hard to evaluate the impact they can potentially have on national welfare. Nevertheless, further screening should be conducted to determine more conclusively if they occur in Finnish ticks.

\section{Conclusions}

In the present study we reported for the first time the occurrence and prevalence of Rickettsia spp. in Finnish ticks. Furthermore, the presence of Bartonella spp. and Candidatus Neoehrlichia mikurensis in Finnish ticks was screened for the first time. Despite the absence of Bartonella spp. and $\mathrm{Ca}$. N. mikurensis in screened samples, further studies should be conducted regarding their occurrence and prevalence in Finland. Borrelia spp. prevalence of ticks collected from south-western Finland was $19.5 \%$, and B. miyamotoi was reported from two new localities in the Archipelago Sea. Rickettsia spp. and B. miyamotoi were also found from larval pools, supporting the notion of naturally occurring transovarial transmission of these pathogens, and emphasizing the importance larvae may have as vectors for human infections. The epidemiological significance of the detected Rickettsia spp. and B. miyamotoi is still unclear and should be further assessed. Finally, with indications of an increase in tick abundance and tick-borne pathogen diversity in Finland, a wider and more comprehensive survey regarding tick-borne pathogens should be made a priority.

\section{Competing interests}

The authors declare that they have no competing interests.

\section{Authors' contributions}

JJS performed most of the field work and laboratory analyses and drafted the manuscript. RP performed morphological identification of tick samples, prospected field survey localities and designed the study. TK designed the study, prospected field survey localities and participated in manuscript revision. $\mathrm{JH}$ and $\mathrm{IV}$ oversaw field surveys in Seili, acquired workforce and funding and organized logistics for field work. ML made the study locality map and performed laboratory analyses. IES and KR designed the study, acquired funding, helped organize logistics and participated in manuscript revision. EJV developed new methodology, provided reagents, designed and performed laboratory analyses and oversaw laboratory work. All authors approved the final version of the manuscript.

\section{Acknowledgements}

Arto Pulliainen (University of Turku) is thanked for providing strains of Bartonella grahamii and B. quintana to be used as positive controls in the analyses. The company Biotop is thanked for professional help according to the lab consumables. This study was supported by the Turku University Foundation, the Ella and Georg Ehrnrooth Foundation, Jenny and Antti Wihuri Foundation, and Finnish Cultural Foundation, Varsinais-Suomi Regional Fund. Special thanks go to MD-PhD Sakari Alhopuro for his financial support. We also wish to thank Toni Hytönen and Omar Badawieh for their help with the field surveys, and the city of Turku and Metsähallitus for their help with field survey logistics. Finally, we would like to thank Nina Nupponen and her dog Sir Nelson for providing us with I. persulcatus samples.

\section{Author details}

${ }^{1}$ Department of Biology, University of Turku, FI-20014 Turku, Finland. ${ }^{2}$ Archipelago Research Institute, University of Turku, FI-20014 Turku, Finland. ${ }^{3}$ Zoological Museum, Department of Biology, University of Turku, Fl-20014 Turku, Finland. ${ }^{4}$ Department of Agricultural Sciences, University of Helsinki, FI-00014 Helsinki, Finland.

Received: 13 January 2016 Accepted: 12 March 2016

Published online: 22 March 2016

References

1. Gayle A, Ringdahl E. Tick-borne diseases. Am Fam Physician. 2001;64:461-6.

2. Parola P, Raoult D. Tick-borne bacterial diseases emerging in Europe. Clin Microbiol Infec. 2001;7:80-3.

3. Jones KE, Patel NG, Levy MA, Storeygard A, Balk D, Gittleman JL, et al. Global trends in emerging infectious diseases. Nature. 2008;451:990-3.

4. Hubálek Z. Epidemology of Lyme Borreliosis. In: Lispker D, Jaulhac B, editors. Lyme Borreliosis. Curr Probl Dermatol. Basel: Karger; 2009. p. 31-50.

5. Rudenko N, Golovchenko M, Grubhoffer L, Oliver Jr JH. Updates on Borrelia burgdorferi sensu lato complex with respect to public health. Ticks Tick Borne Dis. 2011;2:123-8.

6. Piesman J, Gern L. Lyme borreliosis in Europe and North America. Parasitology. 2004;129:S191-220.

7. Fukunaga M, Takahashi Y, Tsuruta Y, Matsushita O, Ralph D, McClelland M, et al. Genetic and phenotypic analysis of Borrelia miyamotoi sp. nov., isolated from the ixodid tick Ixodes persulcatus, the vector of Lyme disease in Japan. Int J Syst Evol Micr. 1995;45:804-10. 
8. Kjelland V, Rollum R, Korslund L, Slettan A, Tveitnes D. Borrelia miyamotoi is widespread in Ixodes ricinus ticks in southern Norway. Ticks Tick Borne Dis. 2015;6:516-21

9. Wilhelmsson P, Lindblom P, Fryland L, Ernerudh J, Forsberg P, Lindgren P-E. Prevalence, diversity, and load of Borrelia species in ticks that have fed on humans in regions of Sweden and Åland Islands, Finland with different Lyme Borreliosis incidences. PLoS One. 2013;8:e81433. 81410.81371/journal. pone.0081433

10. Sormunen JJ, Klemola T, Vesterinen EJ, Vuorinen I, Hytönen J, Hänninen J, et al. Assessing the abundance, seasonal questing activity, and Borrelia and tick-borne encephalitis virus (TBEV) prevalence of Ixodes ricinus ticks in a Lyme borreliosis endemic area in Southwest Finland. Ticks Tick Borne Dis. 2016;7:208-15.

11. Chowdri HR, Gugliotta JL, Berardi VP, Goethert HK, Molloy PJ, Sterling SL, et al. Borrelia miyamotoi infection presenting as human granulocytic Anaplasmosis a case report. Ann Intern Med. 2013;159:21-7.

12. Gugliotta JL, Goethert HK, Berardi VP, Telford SR. Meningoencephalitis from Borrelia miyamotoi in an immunocompromised patient. New Engl J Med. 2013:368:240-5.

13. Hovius JWR, de Wever B, Sohne M, Brouwer MC, Coumou J, Wagemakers A, et al. A case of meningoencephalitis by the relapsing fever spirochaete Borrelia miyamotoi in Europe. Lancet. 2013;382:658.

14. Krause PJ, Narasimhan S, Wormser GP, Rollend L, Fikrig E, Lepore T, et al. Human Borrelia miyamotoi infection in the United States. New Engl J Med. 2013;368:291-3

15. Platonov AE, Karan LS, Kolyasnikova NM, Makhneva NA, Toporkova M, Maleev $V$, et al. Humans infected with relapsing fever spirochete Borrelia miyamotoi, Russia. Emerg Infect Dis. 2011;17:1816.

16. Parola P, Paddock CD, Raoult D. Tick-borne rickettsioses around the world: emerging diseases challenging old concepts. Clin Microbiol Rev. 2005;18: 719-56.

17. Lommano E, Bertaiola L, Dupasquier C, Gern L. Infections and coinfections of questing Ixodes ricinus ticks by emerging zoonotic pathogens in Western Switzerland. Appl Environ Microb. 2012;78:4606-12.

18. Overzier E, Pfister K, Thiel C, Herb I, Mahling M, Silaghi C. Diversity of Babesia and Rickettsia species in questing /xodes ricinus: a longitudinal study in urban, pasture, and natural habitats. Vector Borne Zoonotic Dis. 2013;13:559-64.

19. Sprong $H$, Wielinga P, Fonville M, Reusken C, Brandenburg A, Borgsteede F, et al. Ixodes ricinus ticks are reservoir hosts for Rickettsia helvetica and potentially carry flea-borne Rickettsia species. Parasit Vectors. 2009;2:41.

20. Castro L, Gabrielli S, lori A, Cancrini G. Molecular detection of Rickettsia, Borrelia, and Babesia species in Ixodes ricinus sampled in northeastern, central, and insular areas of Italy. Exp Appl Acarol. 2015:66:443-52.

21. May K, Jordan D, Fingerle V, Strube C. Borrelia burgdorferi sensu lato and co-infections with Anaplasma phagocytophilum and Rickettsia spp. in Ixodes ricinus in Hamburg, Germany. Med Vet Entomol. 2015;29:425-9.

22. Burri C, Dupasquier C, Bastic V, Gern L. Pathogens of emerging tick-borne diseases, Anaplasma phagocytophilum, Rickettsia spp., and Babesia spp., in Ixodes ticks collected from rodents at four sites in Switzerland (Canton of Bern). Vector Borne Zoonotic Dis. 2011;11:939-44.

23. De Sousa R, de Carvalho IL, Santos AS, Bernardes C, Milhano N, Jesus J, et al. Role of the lizard Teira dugesii as a potential host for Ixodes ricinus tickborne pathogens. Appl Environ Microbiol. 2012;78:3767-9.

24. Speck S, Perseke L, Petney T, Skuballa J, Pfäffle M, Taraschewski H, et al. Detection of Rickettsia helvetica in ticks collected from European hedgehogs (Erinaceus europaeus Linnaeus, 1758). Ticks Tick Borne Dis. 2013;4:222-6.

25. Schex S, Dobler G, Riehm J, Müller J, Essbauer S. Rickettsia spp. in wild small mammals in lower Bavaria, South-Eastern Germany. Vector Borne Zoonotic Dis. 2010;11:493-502.

26. Nilsson K, Lindquist O, Liu AJ, Jaenson TGT, Friman G, Påhlson C. Rickettsia helvetica in Ixodes ricinus ticks in Sweden. J Clin Microbiol. 1999;37:400-3.

27. Severinsson K, Jaenson T, Pettersson J, Falk K, Nilsson K. Detection and prevalence of Anaplasma phagocytophilum and Rickettsia helvetica in Ixodes ricinus ticks in seven study areas in Sweden. Parasit Vectors. 2010;3:66.

28. Nilsson $\mathrm{K}$, Jaenson TG, Uhnoo I, Lindquist $\mathrm{O}$, Pettersson B, Uhlén $\mathrm{M}$, et al. Characterization of a spotted fever group Rickettsia from Ixodes ricinus ticks in Sweden. J Clin Microbiol. 1997;35:243-7.

29. Wallménius K, Pettersson JHO, Jaenson TGT, Nilsson K. Prevalence of Rickettsia spp., Anaplasma phagocytophilum, and Coxiella burnetii in adult Ixodes ricinus ticks from 29 study areas in central and southern Sweden. Ticks Tick Borne Dis. 2012;3:100-6.
30. Skarphédinsson S, Lyholm BF, Ljungberg M, SØgaard P, Kolmos HJ, Nielsen LP. Detection and identification of Anaplasma phagocytophilum, Borrelia burgdorferi, and Rickettsia helvetica in Danish Ixodes ricinus ticks. APMIS. 2007; 115:225-30.

31. Svendsen CB, Krogfelt KA, Jensen PM. Detection of Rickettsia spp. in Danish ticks (Acari: Ixodes ricinus) using real-time PCR. Scand J Infect Dis. 2009;41: 70-2.

32. Katargina O, Geller J, Ivanova A, Värv K, Tefanova V, Vene S, et al. Detection and identification of Rickettsia species in Ixodes tick populations from Estonia. Ticks Tick Borne Dis. 2015;6:689-94.

33. Radzijevskaja J, Paulauskas A, Aleksandraviciene A, Jonauskaite I, Stanko M, Karbowiak $G$, et al. New records of spotted fever group rickettsiae in Baltic region. Microbes Infect. 2015:17:874-8.

34. Jia N, Zheng Y-C, Jiang J-F, Ma L, Cao W-C. Human Infection with Candidatus Rickettsia tarasevichiae. New Engl J Med. 2013:369:1178-80.

35. Jado I, Oteo JA, Aldámiz M, Gil H, Escudero R, Ibarra V, et al. Rickettsia monacensis and Human Disease, Spain. Emerg Infect Dis. 2007;13:1405-7.

36. Billeter SA, Levy MG, Chomel BB, Breitschwerdt EB. Vector transmission of Bartonella species with emphasis on the potential for tick transmission. Med Vet Entomol. 2008;22:1-15.

37. Dietrich F, Schmidgen T, Maggi RG, Richter D, Matuschka F-R, Vonthein R, et al. Prevalence of Bartonella henselae and Borrelia burgdorferi sensu lato DNA in Ixodes ricinus ticks in Europe. Appl Environ Microbiol. 2010;76:1395-8.

38. Morozova OV, Cabello FC, Dobrotvorsky AK. Semi-nested PCR detection of Bartonella henselae in Ixodes persulcatus ticks from Western Siberia, Russia. Vector Borne Zoonotic Dis. 2004:4:306-9.

39. Cotté V, Bonnet S, Le Rhun D, Le Naour E, Chauvin A, Boulouis H-J, et al. Transmission of Bartonella henselae by Ixodes ricinus. Emerg Infect Dis. 2008; 14:1074-80.

40. Schorn S, Pfister K, Reulen H, Mahling M, Silaghi C. Occurrence of Babesia spp., Rickettsia spp. and Bartonella spp. in Ixodes ricinus in Bavarian public parks, Germany. Parasit Vectors. 2011:4:135.

41. Podsiadly E, Chmielewski T, Sochon E, Tylewska-Wierzbanowska S. Bartonella henselae in Ixodes ricinus ticks removed from dogs. Vector Borne Zoonotic Dis. 2007;7:189-92

42. Wormser GP, Pritt B. Update and commentary on four emerging tick-borne infections: Ehrlichia muris-like agent, borrelia miyamotoi, deer tick virus, heartland virus, and whether ticks play a role in transmission of Bartonella henselae. Infect Dis Clin N Am. 2015;29:371-81.

43. Reis $C$, Cote $M$, Le Rhun $D$, Lecuelle $B$, Levin ML, Vayssier-Taussat $M$, et al. Vector competence of the tick Ixodes ricinus for transmission of Bartonella birtlesii. PLoS Negl Trop Dis. 2011;5:e1186.

44. Welinder-Olsson C, Kjellin E, Vaht K, Jacobsson S, Wennerås C. First case of human "candidatus neoehrlichia mikurensis" infection in a febrile patient with chronic lymphocytic leukemia. J Clin Microbiol. 2010:48:1956-9.

45. Fehr JS, Bloemberg GV, Ritter C, Hombach M, Lüscher TF, Weber R, et al. Septicemia caused by tick-borne bacterial pathogen candidatus neoehrlichia mikurensis. Emerg Infect Dis. 2010;16:1127.

46. Loewenich F, Geißdörfer W, Disqué C, Matten J, Schett G, Sakka S, et al. Detection of "candidatus neoehrlichia mikurensis" in two patiens with severe febrile illnesses: evidence of a european sequence variant. J Clin Microbiol. 2010;48:2630-5.

47. Richter D, Matuschka F-R. "Candidatus neoehrlichia mikurensis", Anaplasma phagocytophilum and Lyme disease spirochetes in questing European vector ticks and in feeding ticks removed from people. J Clin Microbiol. 2011. doi:10.1128/JCM.05802-11.

48. Diniz PPVP, Schulz BS, Hartmann K, Breitschwerdt EB. "Candidatus neoehrlichia mikurensis" infection in a dog from Germany. J Clin Microbiol. 2011;49:2059-62.

49. Silaghi C, Woll D, Mahling M, Pfister K, Pfeffer M. Candidatus neoehrlichia mikurensis in rodents in an area with sympatric existence of the hard ticks Ixodes ricinus and Dermacentor reticulatus, Germany. Parasit Vectors. 2012;5:285.

50. Fertner, Mette Ely, et al. "First detection of tick-borne" Candidatus Neoehrlichia mikurensis" in Denmark 2011." Eurosurveillance (Online Edition).2012;17.8:9-11

51. Andersson M, Råberg L. Wild rodents and novel human pathogen candidatus neoehrlichia mikurensis, Southern Sweden. Emerg Infect Dis. 2011;17:1716-8.

52. Andersson M, Bartkova S, Lindestad O, Råberg L. Co-infection with 'candidatus neoehrlichia mikurensis' and Borrelia afzelii in Ixodes ricinus ticks in Southern Sweden. Vector Borne Zoonotic Dis. 2013;13:438-42. 
53. Hornok S, Meli M, Gonczi E, Hofmann-Lehmann R. First evidence of candidatus neoehrlichia mikurensis in Hungary. Parasit Vectors. 2013;6:267.

54. Mäkinen J, Vuorinen I, Oksi J, Peltomaa M, He Q, Marjamäki M, et al. Prevalence of granulocytic Ehrlichia and Borrelia burgdorferi sensu lato in Ixodes ricinus ticks collected from Southwestern Finland and from Vormsi Island in Estonia. Acta Path Micro Im. 2003;111:355-62.

55. Junttila J, Tanskanen R, Tuomi J. Prevalence of Borrelia burgdorferi in selected tick populations in Finland. Scand J Infect Dis. 1994;26:349-55.

56. Junttila J, Peltomaa M, Soini H, Marjamäki M, Viljanen MK. Prevalence of Borrelia burgdorferi in Ixodes ricinus ticks in urban recreational areas of Helsinki. J Clin Microbiol. 1999;37:1361-5.

57. Alekseev A, Dubinina $H$, Jääskeläinen $A$, Vapalahti $O$, Vaheri A. First report on tick-borne pathogens and exoskeletal anomalies in Ixodes persulcatus Schulze (Acari: Ixodidae) collected in Kokkola coastal region, Finland. Int J Acarology. 2007:33:253-258

58. Kearse M, Moir R, Wilson A, Stones-Havas S, Cheung M, Sturrock S, et al. Geneious basic: an integrated and extendable desktop software platform for the organization and analysis of sequence data. Bioinformatics. 2012;28:1647-9.

59. Drummond AJ, Ashton B, Buxton S, Cheung M, Cooper A, Duran C, et al. Geneious vR6.2011.http://www.geneious.com/. Accessed 12 Jan 2016.

60. Filippova NA. Arachnida class: ixodid ticks of the subfamily Ixodinae. Fauna SSSR. Leningdrad: Nauka; 1997.

61. Pichon B, Kahl O, Hammer B, Gray JS. Pathogens and host DNA in Ixodes ricinus nymphal ticks from a German forest. Vector Borne Zoonotic Dis. 2006;6:382-7.

62. Christova I, van de Pol J, Yazar S, Velo E, Schouls L. Identification of Borrelia burgdorferi sensu lato, Anaplasma and Ehrlichia species, and spotted fever group rickettsiae in ticks from Southeastern Europe. Eur J Clin Microbiol Infect Dis. 2003;22:535-42.

63. Cotté V, Bonnet $\mathrm{S}$, Cote M, Vayssier-Taussat M. Prevalence of five pathogenic agents in questing Ixodes ricinus ticks from Western France. Vector Borne Zoonotic Dis. 2009:10:723-30

64. Hubálek Z, Halouzka J. Distribution of Borrelia burgdorferi sensu lato genomic groups in Europe, review. Eur J Epidemol. 1997:13:951-7.

65. Rauter $C$, Hartung T. Prevalence of Borrelia burgdorferi sensu lato genospecies in Ixodes ricinus ticks in Europe: a meta-analysis. Appl Environ Microbiol. 2005;71:7203-16

66. Richter D, Debski A, Hubalek Z, Matuschka F-R. Absence of Lyme disease spirochetes in larval Ixodes ricinus ticks. Vector Borne Zoonotic Dis. 2012;12: 21-7.

67. Burri C, Schumann O, Schumann C, Gern L. Are Apodemus spp. mice and Myodes glareolus reservoirs for Borrelia miyamotoi, Candidatus Neoehrlichia mikurensis, Rickettsia helvetica, R. monacensis and Anaplasma phagocytophilum? Ticks Tick Borne Dis. 2014;5:245-51.

68. Hansford KM, Fonville M, Jahfari S, Sprong H, Medlock JM. Borrelia miyamotoi in host-seeking Ixodes ricinus ticks in England. Epidemiol Infect. 2015;143:1079-87.

69. Platonov A, Karan L, Nadezhda K, Makhneva N, Toporkova M, Maleev V, et al. Humans infected with relapsing fever spirochete Borrelia miyamotoi, Russia. Emerg Infect Dis. 2011;17:1816-23.

70. Crowder C, Carolan H, Rounds M, Honig V, Mothes B, Haag H, et al. Prevalence of Borrelia miyamotoi in Ixodes ticks in Europe and the United States. Emerg Infect Dis. 2014:20:1678-82.

71. Cochez C, Heyman P, Heylen D, Fonville M, Hengeveld P, Takken W, et al. The presence of Borrelia miyamotoi, a relapsing fever spirochaete, in questing Ixodes ricinus in Belgium and in The Netherlands. Zoonoses Pub Health. 2015:62:331-3.

72. Halos L, Vourc'h G, Cotte V, Gasqui P, Barnouin J, Boulous H-J, et al. Prevalence of Anaplasma phagocytophilum, Rickettsia sp. and Borrelia burgdorferi sensu lato DNA in questing Ixodes ricinus ticks from France. Ann NY Acad Sci. 2006;1078:316-9.

73. Hartelt $K$, Oehme R, Frank H, Brockmann SO, Hassler D, Kimmig P. Pathogens and symbionts in ticks: prevalence of Anaplasma phagocytophilum (Ehrlichia sp.), Wolbachia sp., Rickettsia sp., and Babesia sp. in Southern Germany. Int J Med Microbiol. 2004;293 Suppl 37:86-92.

74. Kantsø B, Bo Svendsen C, Moestrup Jensen P, Vennestrøm J, Krogfelt KA Seasonal and habitat variation in the prevalence of Rickettsia helvetica in Ixodes ricinus ticks from Denmark. Ticks Tick Borne Dis. 2010;1:101-3.

75. Rymaszewska A, Piotrowski M. Use of DNA sequences for Rickettsia identification in /xodes ricinus ticks: the first detection of Rickettsia monacensis in Poland. Microbes Infect. 2013;15:140-6.
76. Madeddu G, Mancini F, Caddeo A, Ciervo A, Babudieri S, Maida I, et al. Rickettsia monacensis as cause of Mediterranean Spotted Fever-like IIIness, Italy. Emerg Infect Dis. 2012;18:702-4.

77. Fournier PE, Grunnenberger F, Jaulhac B, Gastinger G, Raoult D. Evidence of Rickettsia helvetica infection in humans, eastern France. Emerg Infect Dis. 2000;6:389-92.

78. Imaoka K, Kaneko S, Tabara K, Kusatake K, Morita E. The first human case of Rickettsia tamurae infection in Japan. Case Rep Dermatol. 2011;3:68-73.

79. Derdakova M, Vaclav R, Pangracova-Blanarova L, Selyemova D, Koci J, Walder G, et al. Candidatus Neoehrlichia mikurensis and its co-circulation with Anaplasma phagocytophilum in Ixodes ricinus ticks across ecologically different habitats of Central Europe. Parasit Vectors. 2014;7:160.

80. Scola BL, Holmberg M, Raoult D. Lack of Bartonella sp. in 167 Ixodes ricinus ticks collected in Central Sweden. Scand J Infect Dis. 2004;36:305-6.

81. Angelakis E, Billeter S, Breitschwerdt E, Chomel B, Raoult D. Potential for tick-borne bartonelloses. Emerg Infect Dis. 2010;16:385

82. Telford SR, Wormser GP. Bartonella spp. Transmission by ticks not established. Emerg Infect Dis. 2010;16:379.

83. Courtney JW, Kostelnik LM, Zeidner NS, Massung RF. Multiplex real-time PCR for detection of Anaplasma phagocytophilum and Borrelia burgdorferi. J Clin Microbiol. 2004:42:3164-8.

84. Vayssier-Taussat M, Moutailler S, Michelet L, Devillers E, Bonnet S, Cheval J, et al. Next generation sequencing uncovers unexpected bacterial pathogens in ticks in Western Europe. PLoS One. 2013;8:e81439. 81410. 81371/journal.pone.0081439.

85. Diaz MH, Bai Y, Malania L, Winchell JM, Kosoy MY. Development of a novel genus-specific real-time PCR assay for detection and differentiation of Bartonella species and genotypes. J Clin Microbiol. 2012;50:1645-9.

86. Labruna MB, Whitworth T, Horta MC, Bouyer DH, McBride JW, Pinter A, et al Rickettsia species infecting Amblyomma cooperi ticks from an area in the State of São Paulo, Brazil, where Brazilian spotted fever is endemic. J Clin Microbiol. 2004;42:90-8.

87. Mediannikov OY, Sidelnikov Y, Ivanov L, Mokretsova E, Fournier P-E, Tarasevich I. Acute tick-borne rickettsiosis caused by Rickettsia heilongjiangensis in Russian Far East. Emerg Infect Dis. 2004;10:810-7.

\section{Submit your next manuscript to BioMed Central and we will help you at every step:}

- We accept pre-submission inquiries

- Our selector tool helps you to find the most relevant journal

- We provide round the clock customer support

- Convenient online submission

- Thorough peer review

- Inclusion in PubMed and all major indexing services

- Maximum visibility for your research

Submit your manuscript at www.biomedcentral.com/submit 